\title{
Role of rumen protozoa in nitrogen digestion in sheep given two isonitrogenous diets
}

\author{
BY K. USHIDA*, J. P. JOUANY† AND P. THIVEND \\ Laboratoire de la Digestion des Ruminants, INRA, Centre de Recherches de \\ Clermont, Theix, 63122 Ceyrat, France
}

(Received 23 August 1985 - Accepted 10 April 1986)

\begin{abstract}
1. The effect of protozoa on digestion in the rumen was studied using either defaunated or faunated sheep.
2. Six wethers, each fitted with rumen and simple duodenal cannulas, were given two isonitrogenous diets containing either lucerne (Medicago sativa) hay (diet L) or sodium hydroxide-treated wheat straw (diet S). The diets were given in eight equal portions per day at 3-h intervals. The mean intake of dry matter, $53 \mathrm{~g} / \mathrm{kg}$ body-weight ${ }^{0.75}$ per $\mathrm{d}$, was similar for the two diets and each diet had a similar digestible organic matter content. Diet L promoted a large protozoal population and was rich in nitrogen sources of low rumen-degradability, while diet $\mathbf{S}$ supported a smaller protozoal population and was rich in rumen-degradable $\mathbf{N}$.

3. Digesta flow at the duodenum was estimated by means of a dual-marker technique using chromium-mordanted lucerne hay and polyethylene glycol as markers. The microbial flow at the duodenum was estimated using diaminopimelic acid (DAPA), nucleic-acid purine bases (PB) and ${ }^{35} \mathrm{~S}$ incorporation simultaneously. The different microbial markers were compared in the defaunated sheep. Protozoal $\mathrm{N}$ contribution was estimated in faunated sheep.

4. Defaunated sheep had lower rumen ammonia concentrations and molar proportions of butyric acid than faunated sheep, but they had higher molar proportions of propionic acid.

5. Rumen organic matter digestion was reduced by defaunation, but this decrease was compensated for by increased intestinal digestion.

6. There was a net increase of $\mathrm{N}$ flow (approximately $10 \mathrm{~g} / \mathrm{d}$ ) between mouth and duodenum in defaunated sheep. This was explained by increases in both microbial and dietary $\mathrm{N}$ flows from the rumen compared with faunated sheep.

7. The influence of protozoa on solid- and liquid-phase retention times in the rumen is discussed, as well as the protozoal contribution to microbial $\mathrm{N}$ flow in the duodenum of faunated sheep.
\end{abstract}

Although some work has demonstrated the proteolytic activity of protozoa (Warner, 1956; Williams et al. 1961; Abou Akkada \& Howard, 1962), the quantitative contribution of these micro-organisms to the degradation of feed protein in the rumen is still unclear. Moreover, few in vivo experiments have examined the effect of protozoa on rumen bacterial protein synthesis (Lindsay \& Hogan, 1972; Ushida et al. 1984). Recently, Australian workers (Bird \& Leng, 1978; Bird et al. 1979) demonstrated the positive effect of defaunation on animal growth when given a high-energy diet with low content of rumen-undegradable protein. These results suggest that defaunation increases protein flow to the small intestine as suggested by Veira et al. (1984), and this increase in the protein available to the animal has a marked effect on animal performance under circumstances in which the intestinal protein supply is limiting.

The objective of the present study was, therefore, to investigate quantitatively the contribution of protozoa to nitrogen digestion in sheep, and particularly the effect of defaunation on the passage of dietary and microbial $\mathrm{N}$ to the duodenum. The protozoal contribution to duodenal $\mathrm{N}$ is also discussed.

* Present address: Department of Animal Science, Faculty of Agriculture, Kyoto University, Kyoto 606, Japan.

$\dagger$ For reprints. 
Table 1. Composition of diets

\begin{tabular}{lcc}
\hline \hline Diet... & $\mathrm{L}$ & $\mathrm{S}$ \\
\hline Ingredient (g/kg) & 650 & - \\
$\quad$ Lucerne (Medicago sativa) hay & - & 668 \\
Sodium hydroxide-treated wheat straw & 300 & 142 \\
Barley & - & 52 \\
Sugar-beet pulp & - & 86 \\
Soya-bean cake & 27 & 9 \\
Groundnut cake & - & 19 \\
Urea & 23 & 24 \\
Wheat straw & 921 & 898 \\
Vitamin-mineral supplement* & 20 & 19 \\
Chromium-mordanted lucerne hay & $25 \cdot 0$ & 43.0 \\
Chemical composition & 9.82 & 6.48 \\
Organic matter (g/kg DM) & & \\
Nitrogen (g/kg DM) & N solubility $\dagger$ \\
Metabolizable energy $\dagger(\mathrm{MJ} / \mathrm{kg} \mathrm{DM})$ & \\
\hline
\end{tabular}

DM, dry matter.

* Contained vitamins and minerals $(\mathrm{g} / \mathrm{kg} \mathrm{DM})$ as folows: $\mathrm{Ca}\left(\mathrm{H}_{2} \mathrm{PO}_{4}\right)_{2} 550, \mathrm{NaCl} 260$, sulphur powder 10 , $\mathrm{MgSO}_{4} 90, \mathrm{Na}_{2} \mathrm{SO}_{4} 70$, trace elements $20\left(\mathrm{ZnSO}_{4} 9 \cdot 5, \mathrm{MnSO}_{4} 4 \cdot 8, \mathrm{CuSO}_{4} 1 \cdot 0, \mathrm{FeSO}_{4} 4 \cdot 7, \mathrm{CoSO}_{4} 20 \mathrm{mg}, \mathrm{CaI}_{2}\right.$ $35 \mathrm{mg}, \mathrm{Na}_{2} \mathrm{SeO}_{3} 10 \mathrm{mg}$ ); vitamin A $0 \cdot 3$, vitamin $\mathrm{D}_{3} 0 \cdot 1$, vitamin E 1.0 .

$\dagger$ Calculated with the values from Institut National de la Recherche Agronomique (1978).

\section{MATERIALS AND METHODS}

\section{Animals and diets}

Six Texel wethers, 1-2 years old and weighing $60 \mathrm{~kg}$ body-weight, were used. Each sheep was fitted with a rumen cannula $(60 \mathrm{~mm}$ internal diameter) and a simple duodenal cannula (20 mm internal diameter). They were defaunated (Jouany \& Senaud, 1979a) 2 months before the start of the experiment. At the end of the defaunated period (period 1), the sheep were inoculated with rumen contents taken from sheep given various diets (period 2).

Two isonitrogenous diets were given at the rate of $53 \mathrm{~g}$ dry matter $/ \mathrm{kg}$ body-weight ${ }^{0.75}$ per d. One diet (L), which favoured a large protozoal population and which was high in poorly degradable protein, was composed mainly of lucerne (Medicago sativa) hay. The other diet (S), which did not promote a large protozoal population and which was rich in highly degradable protein, was composed mainly of sodium hydroxide-treated wheat straw. The details of the diets are given in Table 1 . Both diets were pelleted and given in eight equal meals daily at 3-h intervals by means of an automatic feeder.

\section{Experimental procedure}

The experiment consisted of two main periods (period 1, sheep defaunated; period 2, sheep refaunated), each divided into two sub-periods. The six sheep were divided into two groups of three (groups 1 and 2). During the first sub-period of periods 1 and 2, group 1 was given diet $\mathrm{L}$ and group 2 diet $\mathrm{S}$. The feeding was switched in the second sub-period: group 1 was given diet $S$ and group 2 diet L. Each sub-period lasted for 6 weeks, consisting of a 3-week period of adaptation to the diet and a 3-week period of sampling.

Chromium-mordanted lucerne hay, prepared as described by Uden et al. (1980), was incorporated into the diet and given at a rate of $2 \mathrm{~g} \mathrm{Cr} / \mathrm{d}$. A solution of polyethylene glycol (PEG; molecular weight 4000) was infused via the rumen cannula at a rate of $30 \mathrm{~g} \mathrm{PEG} / \mathrm{d}$. 
These markers were used simultaneously and the introduction began 1 week before the sampling period. $\mathrm{Na}_{2}{ }^{35} \mathrm{SO}_{4}$ was included in the solution of PEG $3 \mathrm{~d}$ before the collection of duodenal digesta and its infusion continued for $9 \mathrm{~d}$ at the rate of $250 \mu \mathrm{Ci} / \mathrm{d}$ per animal.

\section{Collection of faeces, duodenal digesta and rumen contents}

The 1st week (days 1-7) of the sampling period for each trial was used for faeces collection. Duodenal digesta $(70 \mathrm{ml})$ was taken every $2 \mathrm{~h}$ on days 8 and 9 . Half of each duodenal sample was filtered through a nylon filter (Blutex XX; Tripette \& Renaud, Paris), $250 \mu \mathrm{m}$ mesh, immediately after being taken. Filtrates and whole digesta were then pooled separately and stored at $-20^{\circ}$. Rumen contents $(400 \mathrm{ml})$ were taken every $2 \mathrm{~h}$ for $10 \mathrm{~h}$ on day 10; samples were combined and rumen bacteria obtained by differential centrifugation (Jouany \& Thivend, 1972). The isolated bacteria were then freeze-dried immediately. Rumen contents $(250 \mathrm{ml})$ were taken at $1,2,4,8,12,24$ and $30 \mathrm{~h}$ after cessation of marker infusions on day 13 and stored at $-20^{\circ}$. These samples were used to determine the rate of passage of liquid, solid and microbial phases from the rumen.

During the faunated period, protozoal numbers were determined by the method of Jouany et al. (1981) on samples taken $2 \mathrm{~h}$ after feeding on at least five successive days.

\section{Chemical analyses}

Dry matter (DM) content was determined by drying at $80^{\circ}$ for $48 \mathrm{~h}$ and organic matter $(\mathrm{OM})$ content was determined by ashing at $600^{\circ}$ for $6 \mathrm{~h}$. Total $\mathrm{N}$ was determined by a Kjeldahl method and ammonia- $\mathrm{N}$ in rumen and duodenal contents as described by Weatherburn (1967). Rumen volatile fatty acid (VFA) analysis was carried out as described by Jouany (1982). PEG was determined turbidimetrically as described by Malawer \& Powel (1967) and Cr was determined using a modified method of Mathieson (1970). Nucleic acid content was estimated by measurement of the purine bases (PB) (Ushida et al. 1985).

$\alpha, \epsilon$-Diaminopimelic acid (DAPA) was determined using ion-exchange chromatography (Collombier, 1981). Organic ${ }^{35} \mathrm{~S}$ was measured as described by Mathers \& Miller (1980) using Instagel (Packard Instrument Corp., Grove, USA) as scintillation fluid and a Tricarb 460 CD spectrometer (Packard Instrument Corp.).

\section{Calculations}

The amount of each constituent entering the duodenum was calculated using a dual-marker technique (Faichney, 1975), based on $100 \%$ recovery of both $\mathrm{PEG}$ and $\mathrm{Cr}$. The measured mean recovery rates of PEG in periods 1 and 2 were 0.942 (SE 0.030 ) and 0.956 (SE 0.026), respectively, while those for $\mathrm{Cr}$ were 0.925 (SE 0.027) and 0.957 (SE 0.021). These results indicate that there were no systematic differences in marker recovery between deiaunated and faunated sheep.

Estimation of microbial $\mathrm{N}(\mathrm{MN})$ flow was made by dividing the amount of microbial marker entering the duodenum by the ratio of the same marker: $\mathrm{N}$ content of the bacteria.

Rumen-undegraded feed protein was estimated by subtraction of $\mathrm{MN}$ and endogenous $\mathrm{N}$ from duodenal non- $\mathrm{NH}_{3}-\mathrm{N}$ (NAN). Endogenous $\mathrm{N}$ flow was assumed to be $1 \mathrm{~g} / \mathrm{d}$ (Weston \& Hogan, 1967).

Rumen fractional turnover rates were estimated by fitting the determined marker concentrations to the equation $C=C_{0} \mathrm{e}^{-k t}$ (Faichney, 1975), where $C_{0}$ and $C$ are the concentrations of the marker at time 0 and time $t$ respectively, and $k$ is the fractional turnover rate of the selected marker and associated phase. Pool sizes of PEG and Cr were estimated by multiplying the amount of marker introduced into the rumen $(\mathrm{g} / \mathrm{h})$ by the retention time of the marker (h). Division of PEG and $\mathrm{Cr}$ pool sizes by corresponding $C_{0}$ values gave the rumen fluid volume and size of the rumen DM pool respectively. 


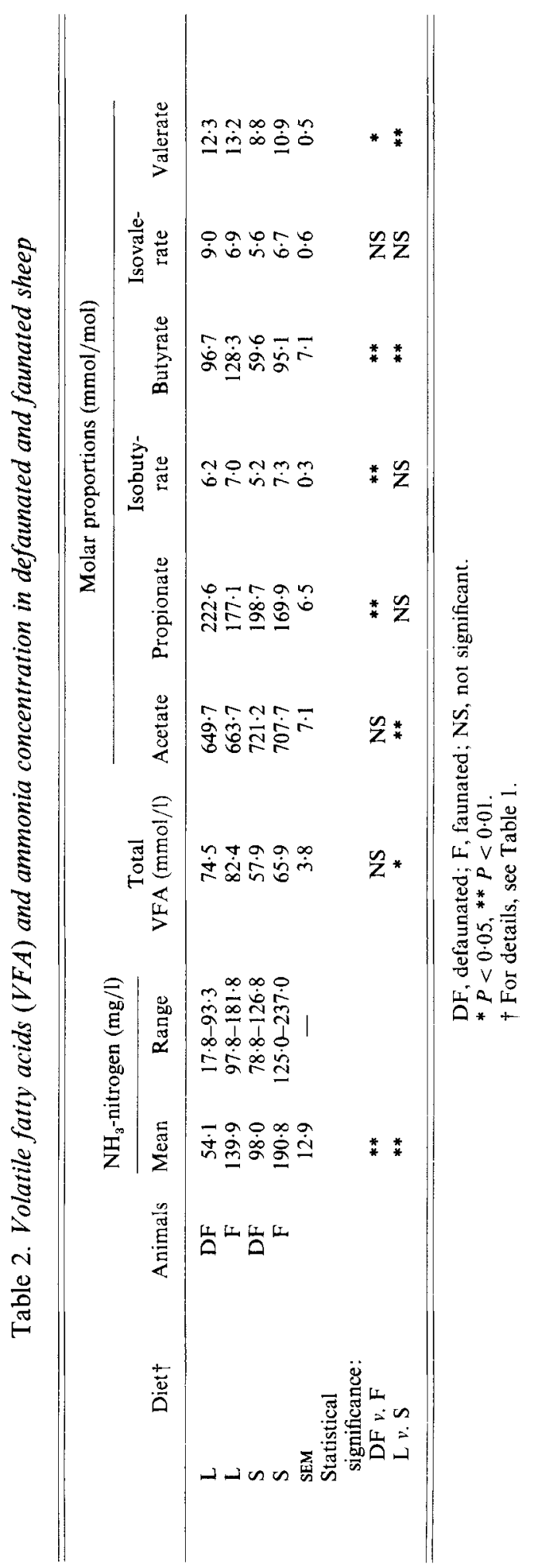


Table 3. Organic matter $(O M)$ digestion in defaunated and faunated sheep

\begin{tabular}{|c|c|c|c|c|c|}
\hline \multirow[b]{2}{*}{$\operatorname{Diet} \dagger$} & \multirow[b]{2}{*}{ Animals } & \multirow{2}{*}{$\begin{array}{l}\text { OM intake } \\
(\mathrm{g} / \mathrm{d})\end{array}$} & \multicolumn{2}{|c|}{$\begin{array}{l}\text { OM apparently digested } \\
(\mathrm{g} / \mathrm{d}) \text { in the: }\end{array}$} & \multirow{2}{*}{$\begin{array}{l}\text { Whole-tract } \\
\text { digestibility }\end{array}$} \\
\hline & & & Rumen & Intestine & \\
\hline $\mathrm{L}$ & DF & 1019 & 299 & 302 & 0.590 \\
\hline $\mathrm{L}$ & $\mathrm{F}$ & 1032 & 448 & 186 & 0.614 \\
\hline $\mathbf{S}$ & DF & 1059 & 324 & 294 & 0.592 \\
\hline $\mathbf{S}$ & F & 1064 & 415 & 220 & 0.597 \\
\hline SEM & & 4 & 15 & 13 & 0.005 \\
\hline \multicolumn{6}{|l|}{$\begin{array}{l}\text { Statistical } \\
\text { significance: }\end{array}$} \\
\hline DF $v . F$ & & ** & $* *$ & ** & NS \\
\hline L v. S & & $* *$ & NS & NS & NS \\
\hline
\end{tabular}

DF, defaunated; F, faunated; NS, not significant.

** $P<0.01$.

$\dagger$ For details, see Table 1.

\section{Statistical analyses}

The values from one sheep given diet $S$ in the first sub-period in period 1 were eliminated because of feed refusal. The values were analysed, therefore, according to the analysis of variance for unbalanced data (Gill, 1978). Comparison between the MN flow estimation by three marker methods was made using one-way analysis of variance (Snedecor \& Cochran, 1971).

\section{RESULTS}

There was no protozoal contamination throughout the defaunated period. Sheep fed on diets $\mathrm{L}$ and $\mathrm{S}$ had $7.6 \times 10^{5}$ protozoa $/ \mathrm{ml}$ and $3.5 \times 10^{5}$ protozoa $/ \mathrm{ml}$ respectively during the faunated period. Dietary effects on the numbers of protozoa were highly significant $(P<0.01)$. Entodinium sp. accounted for more than $90 \%$ of the mixture of protozoa with both diets. Polyplastron multivesiculatum accounted for $5-6 \%$ of the population, while holotrichs accounted for only 0.5-1\%. Diet L favoured the development of Entodinium sp. and $P$. multivesiculatum but the holotrichs were not affected by this diet.

Rumen fermentation patterns are shown in Table $2 . \mathrm{NH}_{3}$ levels in the defaunated animals were lower than those in the faunated animals $(P<0.01)$ and they were lower with diet $\mathrm{L}$ than with diet $\mathrm{S}(P<0 \cdot 01)$. Sometimes extremely low rumen $\mathrm{NH}_{3}$ levels were observed in some defaunated sheep given diet $\mathrm{L}$ : for example, $17 \cdot 8,28 \cdot 0,49 \cdot 0 \mathrm{mg} \mathrm{NH} \mathrm{NH}_{3}-\mathrm{N} / 1$ (see Table 2). Rumen total VFA concentration was lower in defaunated sheep than in faunated sheep, but the difference was not statistically significant. Dietary effects on total VFA concentration were also apparent; diet $L$ promoted a significantly higher total VFA concentration than did diet $S$. In the VFA mixture, defaunation increased the molar proportion of propionic acid $\left(\mathrm{C}_{3}\right)$ and reduced the proportions of butyric acid $\left(\mathrm{C}_{4}\right)$ and valeric acid $\left(\mathrm{C}_{5}\right)$. Diet had a clear effect on the molar proportions of acetic acid $\left(\mathrm{C}_{2}\right), \mathrm{C}_{4}$ and $\mathrm{C}_{5}$, but it had little effect on $\mathrm{C}_{3}$ and branched-chain VFA. The $\mathrm{C}_{2}$ proportion was higher and the proportions of $\mathrm{C}_{4}$ and $\mathrm{C}_{5}$ were lower with diet $\mathrm{S}$ than with diet $\mathrm{L}$.

The OM digestibilities in the whole digestive tract were similar for the two diets (Table 3). Although defaunation reduced rumen OM digestion, the digestibility in the whole tract was not affected. This suggests that defaunation caused a shift in digestion from the rumen 


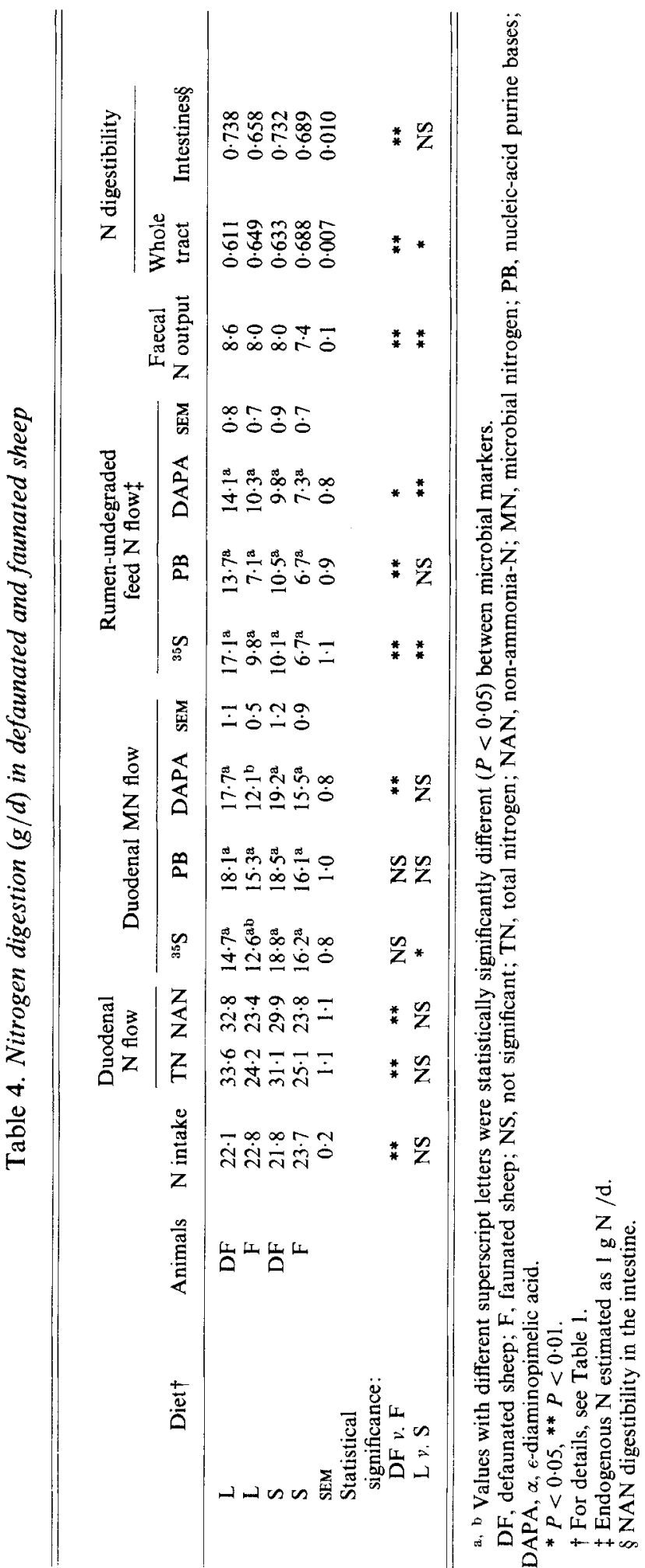


Table 5. Efficiency of microbial protein synthesis and feed nitrogen degradability in defaunated and faunated sheep

\begin{tabular}{|c|c|c|c|c|c|c|c|c|c|}
\hline \multirow[b]{2}{*}{ Diet $†$} & \multirow[b]{2}{*}{ Animals } & \multicolumn{4}{|c|}{$\begin{array}{c}\text { Efficiency of microbial } \\
\text { protein synthesis } \\
\text { ( } \mathrm{N} / \mathrm{kg} \text { OMDR) }\end{array}$} & \multicolumn{4}{|c|}{$\begin{array}{c}\text { Feed } N \text { degradability } \\
\text { in the rumen } \\
(\mathrm{g} / \mathrm{kg} \mathrm{N} \text { intake })\end{array}$} \\
\hline & & ${ }^{35} \mathrm{~S}$ & PB & DAPA & SEM & ${ }^{35} \mathrm{~S}$ & PB & DAPA & SEM \\
\hline $\mathbf{L}$ & DF & $50 \cdot 5^{\mathrm{a}}$ & $63 \cdot 0^{\mathrm{a}}$ & $60 \cdot 6^{a}$ & 5.0 & $225^{\mathrm{a}}$ & $381^{a}$ & $360^{a}$ & 38 \\
\hline $\mathrm{L}$ & F & $28 \cdot 1^{\mathrm{a}}$ & $34 \cdot 2^{\mathrm{b}}$ & $26 \cdot 9^{\mathrm{a}}$ & $1 \cdot 2$ & $571^{\mathrm{a}}$ & $690^{a}$ & $548^{\mathrm{a}}$ & 28 \\
\hline $\bar{S}$ & $\mathrm{DF}$ & $58 \cdot 2^{a}$ & $57 \cdot 2^{\mathrm{a}}$ & $59 \cdot 2^{\mathrm{a}}$ & $3 \cdot 7$ & $538^{\mathrm{a}}$ & $520^{\mathrm{a}}$ & $553^{a}$ & 41 \\
\hline$S$ & $\mathrm{~F}$ & $38 \cdot 5^{\mathrm{a}}$ & $38 \cdot 7^{a}$ & $37 \cdot 3^{a}$ & $1 \cdot 5$ & $715^{\mathrm{a}}$ & $716^{a}$ & $688^{a}$ & 32 \\
\hline SEM & & $3 \cdot 2$ & $4 \cdot 4$ & 3.8 & & 49 & 41 & 36 & \\
\hline \multicolumn{10}{|l|}{$\begin{array}{l}\text { Statistical } \\
\text { significance: }\end{array}$} \\
\hline DF v. F & & $* *$ & $* *$ & $* *$ & & ** & $* *$ & ** & \\
\hline $\mathbf{L} v, \mathbf{S}$ & & NS & NS & NS & & ** & NS & ** & \\
\hline
\end{tabular}

a, b Values with different superscript letters were statistically significantly different $(P<0.05)$ between microbial markers.

DF, defaunated sheep; F, faunated sheep; NS, not significant; OMDR, organic matter apparently digested in the rumen; PB, nucleic-acid purine bases; DAPA, $\alpha, \epsilon$-diaminopimelic acid.

** $P<0.01$.

$\dagger$ For details, see Table 1.

to the intestines. $\mathrm{N}$ flowing into the duodenum was significantly higher in defaunated sheep than in faunated sheep $(P<0.01)$ (Table 4). A net gain in $\mathrm{N}$ between the mouth and duodenum was observed in the defaunated sheep (approximately $10 \mathrm{~g} \mathrm{~N} / \mathrm{d}$ ). MN flowing into the duodenum was higher in defaunated sheep than that in faunated sheep. However, the differences were not significant, except when MN was estimated using the DAPA method. Therefore, defaunation increases considerably the amount of feed $\mathrm{N}$ which escaped rumen degradation. Concerning the effect of diet on $\mathrm{MN}$ flow, diet $\mathrm{S}$ promoted a slightly larger mean MN flow than did diet $\mathrm{L}$. The amount of rumen-undegraded feed $\mathrm{N}$ was also higher with diet $\mathrm{L}$ than with diet $\mathrm{S}$. Faecal $\mathrm{N}$ output was slightly but significantly higher in defaunated sheep $(P<0.01)$, consequently $\mathrm{N}$ digestibility was reduced by defaunation, independent of diet. However, despite this, the amount of NAN digested in the intestines was much greater in defaunated than in faunated sheep $(P<0.01)$.

Efficiency of MN synthesis and feed degradability in the rumen are shown in Table 5. Comparison of the three different microbial markers did not show a significant difference between the methods of estimation, except for the difference between PB and DAPA methods in the faunated sheep given diet L. MN synthesis in defaunated sheep was 1.5-2-fold more efficient than those in faunated sheep. Diet $S$ promoted higher efficiency of $\mathrm{MN}$ synthesis than did diet $\mathrm{L}$ in faunated sheep, while diet had little effect in defaunated sheep. The degradability of feed $\mathrm{N}$ in the faunated animals was between 1.3 and 2 times higher than that in the defaunated animals. In accord with the predicted solubility, degradability of $\mathrm{N}$ in diet $\mathrm{S}$ was about 1.5 times higher than that in diet $\mathrm{L}(0.43 v .0 .25)$.

The chemical composition of bacteria was affected by defaunation (Table 6). The $\mathrm{N}$, nucleic acid and DAPA contents were higher in bacteria taken from defaunated sheep than in those taken from faunated sheep. Dietary effects on the chemical composition of bacteria were less apparent.

Turnover rates and retention times of the rumen liquid-phase (estimated by PEG dilution 
Table 6. Chemical composition of bacteria $(\mathrm{g} / \mathrm{kg}$ dry matter $)$

\begin{tabular}{lccccc}
\hline Diet $\dagger$ & Animals & OM & Nitrogen & PB $\neq$ & DAPA \\
\hline L & DF & 890 & 84 & $91 \cdot 0$ & $3 \cdot 5$ \\
L & F & 873 & 79 & $72 \cdot 5$ & $2 \cdot 8$ \\
S & DF & 878 & 87 & $98 \cdot 3$ & $3 \cdot 2$ \\
S & F & 867 & 81 & 85.7 & $2 \cdot 5$ \\
SEM & & 4 & 1 & 3.6 & $0 \cdot 1$ \\
Statistical & & & & & \\
significance: & & NS & $*$ & $* *$ & $* *$ \\
DF $v$. F & & NS & NS & $*$ & NS \\
L $v$. S & & & \\
\hline
\end{tabular}

DF, defaunated sheep; F, faunated sheep; OM, organic matter; PB, nucleic-acid purine bases; DAPA, $\alpha$, $\epsilon$-diaminopimelic acid.

$* P<0.05, * * P<0.01$.

$\dagger$ For details, see Table 1 .

$¥$ Purine bases content is expressed as g yeast RNA.

Table 7. Retention time $(h)$ of liquid-phase, solid-phase and microbial markers in defaunated and faunated sheep

\begin{tabular}{|c|c|c|c|c|c|c|}
\hline $\operatorname{Diet} \dagger$ & Animals & PEG & Mordanted $\mathbf{C r}$ & Organic ${ }^{35} \mathrm{~S}$ & $\begin{array}{l}\text { Rumen } \\
\text { fluid } \\
\text { volume (1) }\end{array}$ & $\begin{array}{c}\text { Rumen } \\
\text { DM } \\
\text { pool }(\mathrm{kg})\end{array}$ \\
\hline $\mathbf{L}$ & DF & $12 \cdot 5$ & $15 \cdot 6$ & 13.9 & $5 \cdot 8$ & 0.49 \\
\hline $\mathrm{L}$ & $\mathrm{F}$ & 15.9 & $19 \cdot 1$ & $27 \cdot 6$ & 5.9 & 0.57 \\
\hline $\mathbf{S}$ & DF & $10 \cdot 4$ & $12 \cdot 7$ & $15 \cdot 0$ & $5 \cdot 6$ & 0.42 \\
\hline $\mathbf{S}$ & $\mathrm{F}$ & $11 \cdot 4$ & $14 \cdot 5$ & $22 \cdot 1$ & $6 \cdot 8$ & 0.51 \\
\hline SEM & & 0.5 & 0.8 & $1 \cdot 4$ & 0.3 & 0.03 \\
\hline \multicolumn{7}{|c|}{$\begin{array}{l}\text { Statistical } \\
\text { significance: }\end{array}$} \\
\hline DF v. F & & $* *$ & $* *$ & $* *$ & NS & NS \\
\hline L v. S & & $* *$ & $* *$ & NS & NS & NS \\
\hline
\end{tabular}

DF, defaunated sheep; F, faunated sheep; NS, not significant; PEG, polyethylene glycol; DM, dry matter. ** $P<0.01$.

$\dagger$ For details, see Table 1.

rate), solid-phase (estimated by $\mathrm{Cr}$-dilution rate), and microbial proteins (estimated by organic ${ }^{35}$ S-dilution rate) are shown in Table 7 and Fig. 1. All three fractions were retained longer in faunated than in defaunated sheep. A dietary effect was also observed in the liquidand solid-phase retention times. Organic ${ }^{35} \mathrm{~S}$ concentrations decreased at a rate similar to $\mathrm{Cr}$ in defaunated sheep, but ${ }^{35} \mathrm{~S}$ was retained much longer than $\mathrm{Cr}$ in faunated sheep (Fig. 1). There were no significant effects of defaunation or diet on rumen fluid volume and on the size of the rumen DM pool.

\section{DISCUSSION}

Diet $\mathrm{L}$, with a higher starch content, promoted a larger protozoal population than diet $\mathrm{S}$. This difference was due mainly to an increased number of Entodinium sp.; holotrich numbers were not affected by dietary conditions. Entodinium sp. are considered to be the most sensitive to dietary changes (Jouany, 1978; Dennis et al. 1983), while holotrich 

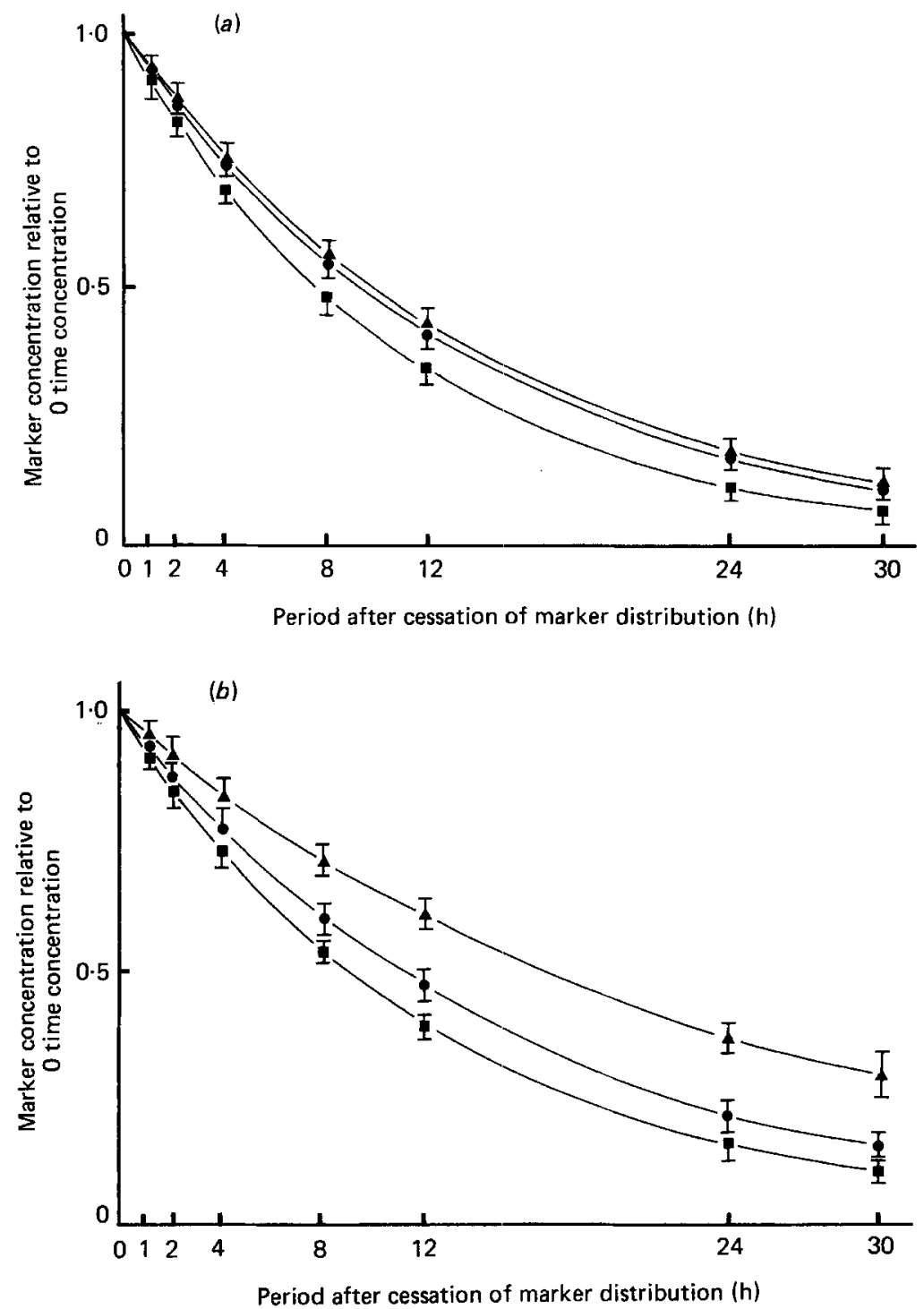

Fig. 1. The mean curves of marker disappearance from the rumen established using the pooled results taken from $(a)$ six defaunated sheep given diet $\mathrm{L}$ and five defaunated sheep given diet $\mathrm{S}$, and $(b)$ six faunated sheep given diet $\mathrm{L}$ and six faunated sheep given diet $S$. Organic ${ }^{35} \mathbf{S}(\boldsymbol{A})$, mordanted chromium (O), polyethylene glycol $(\square)$. Points are mean values, with their standard errors represented by vertical bars.

numbers do not normally vary greatly with the diet (Nakamura \& Kanegasaki, 1969; Eadie et al. 1970; Dehority \& Mattos, 1978; Dennis et al. 1983). The present results confirm these observations.

\section{Effect of defaunation on end-products of rumen fermentation}

The effect of defaunation in decreasing both rumen $\mathrm{NH}_{3}$ and VFA concentrations agrees with previously published results (Coleman, 1981; Demeyer, 1981; Jouany et al. 1981). Protozoal ingestion of bacteria and proteolytic action on dietary protein lead to greater 
rumen $\mathrm{NH}_{3}$ concentrations in faunated animals. Protozoa cannot use ingested protein efficiently; only $50 \%$ of ingested bacterial $\mathrm{N}$ is retained. The remainder returns to the surrounding environment in the form of amino acids which are catabolized to $\mathrm{NH}_{3}$ by the bacteria (Coleman, 1975). Diet $\mathbf{L}$ promoted lower $\mathrm{NH}_{3}$ concentrations, especially in defaunated animals, because that diet contained less soluble $\mathrm{N}$ and more readily-fermentable carbohydrate than diet $\mathrm{S}$. $\mathrm{NH}_{3}$ production from dietary $\mathrm{N}$ degradation may have been less and the bacterial $\mathrm{NH}_{3}$ assimilation rate may have been greater with diet $\mathrm{L}$.

The negative effect of defaunation on total VFA concentration in the present study is related to reduced rumen $\mathrm{OM}$ digestion (Table 3 ). The reduction in $\mathrm{C}_{4}$ concentrations agrees with most observations made in defaunated sheep (Jouany et al. 1981). Since protozoa produce $\mathrm{C}_{2}$ and $\mathrm{C}_{4}$ (Hungate, 1966), increased $\mathrm{C}_{4}$ concentration in faunated sheep is partly due to protozoal $\mathrm{C}_{4}$ production. The increase observed in molar proportion of $\mathrm{C}_{3}$ in defaunated animals was probably induced by a change in rumen flora. Bacteriological studies in defaunated calves have shown that $\mathrm{C}_{2}$-producing species, such as Ruminococcus, are not predominant, while succinate producers, such as Bacteroides, are the predominant species (Bryant \& Small, 1960). Amylolytic species, mainly B. ruminicola and B. amylophilus which produce succinate, increase in the rumen of defaunated animals (Kurihara et al. 1978). These changes may enhance $C_{3}$ production.

\section{Respective roles of bacteria and protozoa in rumen protein degradation}

Both $\mathrm{MN}$ flow and dietary $\mathrm{N}$ which escaped rumen degradation increased in the defaunated sheep. If the endogenous $\mathrm{N}$ flow was not greatly affected by defaunation, the extent of the increase in rumen-undegraded dietary $\mathrm{N}$ was much greater than that in $\mathrm{MN}$ flow. These results show that dietary $\mathbf{N}$ degradability is significantly decreased by defaunation, and agree with the observations made using in vitro and nylon-bag techniques (Kayouli et al. 1983; Ushida \& Jouany, 1985). Protozoa can ingest directly small particulate matter, such as bacteria, starch granules (Coleman \& Hall, 1969) and chloroplasts (Mangan \& Pryor, 1969; West \& Mangan, 1972), and their proteolytic activity has been widely demonstrated (Abou Akkada \& Howard, 1962; Ushida \& Jouany, 1985). Therefore higher dietary N degradability in the faunated rumen seems likely, at least in part, to be due to protozoal proteolysis. The change in the composition of the bacterial flora induced by defaunation would also affect proteolytic activity in the rumen. The accessibility of dietary protein to microbial proteases, which can be considered as a main factor in determining the rate of protein degradation (Ganev et al. 1979), was improved by the more intensive digestion of OM or cellulose (Jouany \& Senaud, 1979b) in the rumen of faunated sheep. Retention time of feed protein in the rumen is another factor which determines the degradation of rumen-insoluble protein. When the turnover rate of rumen contents is high, low protein degradability is observed (Tamminga et al. 1979; Ørskov et al. 1980). In the present study, the mean retention time of mordanted $\mathrm{Cr}$ was longer in the rumen of faunated sheep, which may explain the higher degradation of dietary protein in these animals compared with defaunated sheep.

\section{Measurement of mean retention time of solid particles}

The lucerne hay mordanted with $\mathrm{Cr}$ was ground through a $4 \mathrm{~mm}$ screen before being incorporated in the pelleted diet. After such treatment, lucerne became friable and probably gave very small labelled particles. This assumption is confirmed by the similar retention times of ${ }^{35} \mathrm{~S}$ and $\mathrm{Cr}$ in defaunated sheep. The mean retention time of the total solid phase might be longer than that measured here. 
Influence of protozoa on mean retention times of rumen contents and micro-organisms After inoculation with protozoa, the mean retention time of PEG and mordanted Cr was increased. These results, obtained with roughage-based diets, suggest that protozoa increase the retention times of liquid and small particles in the rumen. They agree with the results reported by Kayouli et al. $(1983,1984)$ obtained with a straw diet, but are contrary to the observations of Faichney \& Griffiths (1978) who observed the opposite effect with a concentrate diet. The effect of protozoa on the retention time of either fluid or solid phases of rumen contents is still difficult to explain. Protozoa can be sequestered by their attachment to the rumen wall or to large feed particles (Bauchop \& Clarke, 1976; Orpin, $1979 a, b$; Abe et al. 1981). They ingest, and therefore sequester, small feed particles, so this sequestration may lengthen the retention time of small feed particles. Contrary to the present results, Orpin \& Letcher (1984) recently reported an increase in retention time of the liquid phase after defaunation. However, their results were obtained from the measurement of marker disappearance rate in the rumen of sheep fed once daily instead of every $3 \mathrm{~h}$, as was the case in the present experiment.

Generally speaking, micro-organisms flow out from the rumen in two ways. They are associated with the liquid phase or attached to the feed particles. Microbial markers would therefore give a value of turnover rate between that of the liquid-phase marker and the solid-phase marker. However, the turnover rate of ${ }^{35} \mathrm{~S}$ was close to that of the $\mathrm{Cr}$-mordanted marker in defaunated sheep but slower than that of the Cr-mordanted marker in faunated sheep. The recycling of ${ }^{35} \mathrm{~S}$ within the rumen presumably lowered its turnover rate. The magnitude of this recycling is not known but it may be increased in faunated animals because of protozoal predation of bacteria. Although the proportions of bacteria associated with the liquid or solid phases which flow out from the rumen are not known exactly, the results obtained in defaunated sheep may indicate that the larger part of the bacteria which flow out from the rumen consists of small-particle-associated bacteria, because there is little recycling of bacterial matter in the rumen of these animals (Demeyer \& Van Nevel, 1979). This could also indicate that the outflow mainly contains liquidassociated bacteria, if it is considered that the mean retention time of large particles is longer than that measured by mordanted $\mathrm{Cr}$. Comparing the retention time of ${ }^{35} \mathrm{~S}$ in defaunated and faunated animals, it can be concluded that protozoa increase the retention time of micro-organisms in the rumen, which can be explained by the sequestration of the protozoa themselves (Weller \& Pilgrim, 1974; Harrison \& McAllan, 1980; Collombier, 1981).

\section{Influence of protozoa on microbial protein synthesis}

Bacterial N flow, which was estimated using DAPA, was higher in defaunated sheep than in faunated sheep; the efficiency of bacterial protein synthesis was also higher in the defaunated animals. The efficiency measured in faunated sheep was close to the value adopted in present protein rationing systems (Institut National de la Recherche Agronomique, 1978; Agricultural Research Council, 1980). Similar results were obtained for MN flow and efficiency of MN synthesis when they were estimated by PB and ${ }^{35} \mathrm{~S}$ methods. These results indicate that protozoal $N$ supply did not compensate for the decrease in bacterial N flow in faunated sheep. Demeyer \& Van Nevel (1979) showed that the efficiency of bacterial protein synthesis was increased by defaunation in an in vitro experiment. They suggested that the lower degradation of bacteria in the defaunated rumen, caused by the absence of predation, would increase the efficiency of microbial synthesis. As discussed earlier, the disappearance of predation and nutritional competition between protozoa and bacteria following defaunation led to a larger bacterial population, which directly explains 
the increased duodenal flow of bacterial cells. Moreover, the higher turnover rate of the rumen liquid phase observed in defaunated animals can partly explain the improvement in the efficiency of microbial protein synthesis in the rumen (Harrison et al. 1975, 1976; Kennedy \& Milligan, 1978).

\section{Comparison of the three methods used to estimate microbial synthesis}

The three different markers used in the present study to measure MN showed relatively good agreement, particularly when comparisons were carried out in defaunated animals, where the comparison is strictly valid. No statistical differences were detected, except between PB and DAPA methods in faunated sheep given diet L. However, the variations between animals were sometimes rather high. The reliability of microbial markers has been intensively discussed in the past decade (e.g. Harrison \& McAllan, 1980). Since it is impossible to verify the results obtained by any marker method by means of an absolute reference, the reliability of a marker can only be assessed in comparative terms. Many simultaneous comparisons between markers have been conducted (Ling \& Buttery, 1978; Smith et al. 1978; Siddons et al. 1979, 1982; Mercer et al. 1980), but it is still difficult to draw a definitive conclusion because of discrepancies between the results. For the nucleicacid method, the problem of dietary contamination of duodenal nucleic acids has been pointed out, and MN flow estimated by the RNA method usually gives high values. In the present study, the protozoal $\mathrm{N}$ contribution to $\mathrm{MN}$ in the duodenum was $20 \%$ with PB-DAPA comparison in the sheep given diet $\mathrm{L}$, while $4 \%$ of $\mathrm{MN}$ was attributable to the protozoa in the sheep given diet $\mathrm{S}$. The value observed with diet $\mathrm{L}$ is similar to that of previously published results from experiments on sheep with a similar size of rumen protozoal population (Harrison et al. 1979; Sutton et al. 1983), but further investigation is needed to verify these estimations by use of markers specific for protozoa, such as phosphatidyl choline (John \& Ulyatt, 1984).

The authors wish to thank Mr J. Lefaivre for surgical preparation of the sheep, $\mathrm{Mr}$ L. l'Hotelier, Mr M. Fabre and Mr P. Pichon for care of the experimental animals and Mrs Bernadette Lassalas, Mrs Marie-Paule Girard and Miss Paulette Journaix for technical assistance. One of the authors (K. U.) is indebted to the French Government (C.I.E.S.) for a grant to work at INRA, Centre de Recherches de Clermont, Theix, France.

\section{REFERENCES}

Abe, M., Iriki, T., Tobe, N. \& Shibui, H. (1981). Applied and Environmental Microbiology 41, 758-765.

Abou Akkada, A. R. \& Howard, B. H, (1962). Biochemical Journal 82, 313-320.

Agricultural Research Council (1980). The Nutrient Requirements of Ruminant Livestock, p. 127. Farnham Royal, Slough: Commonwealth Agricultural Bureaux.

Bauchop, T. \& Clarke, R. T. J. (1976). Applied and Environmental Microbiology 32, 417-422.

Bird, S. H., Hill, H. K. \& Leng, R. A. (1979). British Journal of Nutrition 42, 81-87.

Bird, S. H. \& Leng, R. A. (1978). British Journal of Nutrition 40, 163-167.

Bryant, M. P. \& Small, N. (1960). Journal of Dairy Science 43, 654-667.

Coleman, G. S. (1975). In Digestion and Metabolism in the Ruminant, pp. 149-164. [I. W. McDonald and A. C. I. Warner editors]. Armidale, NSW, Australia: University of New England Publishing Unit.

Coleman, G. S. (1981). Advances in Parasitology 18, 121-163.

Coleman, G. S. \& Hall, F. J. (1969). Tissue and Cell 1, 607-618.

Collombier, J. (1981). Contribution à l'étude du rôle des protozoaires ciliés du rumen dans l'apport d'azote microbien entrant dans le duodenum du ruminant. Thèse de doctorat, Université de Clermont II.

Dehority, B. A. \& Mattos, W. (1978). Applied and Environmental Microbiology 36, 953-958.

Demeyer, D. I. (1981). Agricultural Environment 6, 295-337.

Demeyer, D. I. \& Van Nevel, C. J. (1979). British Journal of Nutrition 42, 51 5-524.

Dennis, S. M., Arambel, M. J., Bartley, E. E. \& Dayton, A. D. (1983). Journal of Dairy Science 66, $1248-1258$.

Eadie, J. M., Hyldgaard-Jensen, J., Mann, S. O., Reid, R. S. \& Whitelaw, F. G. (1970). British Journal of Nutrition 24, $157-177$. 
Faichney, G. J. (1975). In Digestion and Metabolism in the Ruminant, pp. 261-276 [I. W. McDonald and A. C. I. Warner, editors]. Armidale, NSW, Australia: University of New England Publishing Unit.

Faichney, G. J. \& Griffiths, D. A. (1978). British Journal of Nutrition 40, 71-82.

Ganev, G., Ørskov, E. R. \& Smart, R. (1979). Journal of Agricultural Science, Cambridge 93, 651-656.

Gill, J. L. (1978). Design and Analysis of Experiments in the Animal and Medical Sciences, vol. 1, pp. $239-248$. Ames, Iowa: Iowa State University Press.

Harrison, D. G., Beever, D. E. \& Osbourn, D. F. (1979). British Journal of Nutrition 41, $521-527$.

Harrison, D. G., Beever, D. E., Thomson, D. J. \& Osbourn, D. F. (1975). Journal of Agricultural Science, Cambridge 85, 93-101.

Harrison, D. G., Beever, D. E., Thomson, D. J. \& Osbourn, D. F. (1976). Journal of the Science of Food and Agriculture 27, 617-620.

Harrison, D. G. \& McAllan, A. B. (1980). In Digestive Physiology and Metabolism in Ruminants, pp. $205-226$ [Y. Ruckebusch and P. Thivend, editors]. Lancaster: MTP Press.

Hungate, R. E. (1966). The Rumen and Its Microbes, pp. 137-139. New York: Academic Press.

Institut National de la Recherche Agronomique (1978). Alimentation des Ruminants, p. 97. Versailles, France: INRA Publications.

John, A. \& Ulyatt, M. J. (1984). Journal of Agricultural Science, Cambridge 102, 33-44.

Jouany, J. P. (1978). Contribution à l'étude des protozoaires ciliés du rumen: leur dynamique, leur rôle dans la digestion et leur interêt pour le ruminant. Thèse de docteur ès sciences, Université de Clermont II.

Jouany, J. P. (1982). Sciences des Aliments 2, 131-141.

Jouany, J. P. \& Senaud, J. (1979 a). Annales de Biologie Animale, Biochimie, Biophysique 19, 619-624.

Jouany, J. P. \& Senaud, J. (1979b). Annales de Recherches Vétérinaires 10, 261-263.

Jouany, J. P. \& Thivend, P. (1972). Annales de Biologie Animale, Biochimie, Biophysique 12, 679-683.

Jouany, J. P., Zainab, B., Senaud, J., Groliere, C. A., Grain, J. \& Thivend, P. (1981). Reproduction, Nutrition et Développement 21, 874-884.

Kayouli, C., Demeyer, D. I., Van Nevel, C. J. \& Dendooven, R. (1984). Animal Feed Science and Technology 10, $165-172$

Kayouli, C., Van Nevel, C. J. \& Demeyer, D. I. (1983). In Métabolisme et Nutrition Azotés vol. 2, Les colloques de IINRA no. 16, pp. 251-253 [M. Amal and D. Bonin, editors]. Versailles, France: INRA Publications.

Kennedy, P. M. \& Milligan, L. P. (1978). British Journal of Nutrition 39, 105-117.

Kurihara, Y., Takechi, T. \& Shibata, F. (1978). Journal of Agricultural Science, Cambridge 90, 373-381.

Lindsay, J. R. \& Hogan, J. P. (1972). Australian Journal of Agricultural Research 23, 321-330.

Ling, J. R. \& Buttery, P. J. (1978). British Journal of Nutrition 39, 165-175.

Malawer, S. J. \& Powel, D. W. (1967). Gastroenterology 53, 250-256.

Mangan, J. L. \& Pryor, M. J. (1969). Journal of Physiology 200, 18p-19p

Mathers, J. C. \& Miller, E. L. (1980). British Journal of Nutrition 43, 503-514.

Mathieson, J. (1970). Proceedings of the Nutrition Society 29, 30A.

Mercer, J. R., Allen, S. A. \& Miller, E. L. (1980). British Journal of Nutrition 43, 421-433.

Nakamura, K. \& Kanegasaki, S. (1969). Journal of Dairy Science 52, 250-255.

Orpin, G. C. (1979a). Society of General Microbiology Quarterly 7, 31-32.

Orpin, G. C. (1979 b). Society of General Microbiology Quarterly 7, 32.

Orpin, G. C. \& Letcher, A. J. (1984). Animal Feed Science and Technology 10, 145-153.

Ørskov, E. R., Hughes-Jones, M. \& McDonald, I. (1980). In Recent Advances in Animal Nutrition-1980, pp. $85-98$ [W. Haresign, editor]. London: Butterworths.

Siddons, R. C., Beever, D. E. \& Nolan, J. V. (1982). British Journal of Nutrition 48, 377-389.

Siddons, R. C., Beever, D. E., Nolan, J. V., McAllan, A. B. \& MacRae, J. C. (1979). Annales de Recherches Vétérinaires 10, 286-287.

Smith, R. H., McAllan, A. B., Hewitt, D. \& Lewis, P. E. (1978). Journal of Agricultural Science, Cambridge 90 , $557-568$.

Snedecor, G. W. \& Cochran, W. G. (1971). Méthodes Statistiques, 6th ed., pp. 287-333 [H. Boelle \& E. Camhaji, editors]. Paris: Association de Coordination de Technique Agricole.

Sutton, J. D., Knight, R., McAllan, A. B. \& Smith, R. H. (1983). British Journal of Nutrition 49, 419-432.

Tamminga, S.,van der Koelen, C. J. \& Van Vuuren, A. M. (1979). Livestock Production Science 6, $255-262$.

Uden, P., Colucci, P. E. \& Van Soest, P. J. (1980). Journal of the Science of Food and Agriculture 31, 625-632.

Ushida, K. \& Jouany, J. P. (1985). Reproduction, Nutrition et Développement 25, 1075-1081.

Ushida, K., Jouany, J. P., Lassalas, B. \& Thivend, P. (1984). Canadian Journal of Animal Science 64, Suppl. $20-21$.

Ushida, K., Lassalas, B. \& Jouany, J. P. (1985). Reproduction, Nutrition et Développement 25, 1037-1046.

Veira, D. M., Ivan, M. \& Jui, P. Y. (1984). Canadian Journal of Animal Science 64, Suppl. 22-23.

Warner, A. C. I. (1956). Journal of General Microbiology 14, 749-762.

Weatherburn, M. W. (1967). Analytical Chemistry 39, 971-974.

Weller, R. A. \& Pilgrim, A. F. (1974). British Journal of Nutrition 32, 341-351.

West, J. \& Mangan, J. L. (1972). Proceedings of the Nutrition Society 31, 108A-109A.

Weston, R. H. \& Hogan, J. P. (1967). Australian Journal of Biological Science 20, 967-973.

Williams, P. D., Davis, R. E., Doetsh, R. N. \& Gutierrez, J. (1961). Applied Micobiology 9, 405-409. 